\title{
Study on the Teaching Reform of Asset Appraisal Specialty Oriented by "Integration of Curriculum and Profession"*
}

\author{
Haijun Kang \\ Fuzhou University of International Studies and Trade \\ Fuzhou, China 350202
}

\begin{abstract}
The reform for the professional qualification examination of asset appraisers has brought new opportunities and challenges for the talent cultivation of asset appraisal, and the reform of teaching mode of asset appraisal gets imperative. Starting from the connotation of the talent training mode of "Integration of Curriculum and Profession" in asset appraisal, this paper analyzes the characteristics of the talent training mode of "Integration of Curriculum and Profession", and taking Fuzhou University of International Studies and Trade as an example, analyzes the status quo and existing problems of the teaching mode of "Integration of Curriculum and Profession" in asset appraisal from the aspects of talent training specifications, curriculum setting, student guidance and motivation, internship training base construction and teacher training, and finally, it proposes the teaching reform of asset appraisal based on " Integration of Curriculum and Profession".
\end{abstract}

Keywords-integration of curriculum and profession; asset appraisal; teaching reform; integration of production and education

\section{INTRODUCTION}

With the continuous development of China's economy and the rapid development of various industries, the professional value of asset appraisal is constantly improving, the comprehensive strength of the asset assessment industry is continuously enhanced, and the demand for asset appraisers is growing. According to statistics, as of the end of 2016, there were more than 3,300 national asset assessment agencies, more than 100,000 employees but only 34,000 asset appraisers in the asset assessment industry. The number of asset appraisers still does not meet the development needs of the asset appraisal industry. The number lack of asset appraisers is largely resulted from the limitations of registration. According to the application for the examination, the undergraduate students must meet the requirements of "obtaining bachelor degrees of economics and of engineering, working for 3 years, and engaging in the work of asset assessment for 1 year or more", and the limitations of work experience make it impossible for students to apply for the exam for a asset appraiser.

In May 2017, the Notice of the Department of Finance of

*Project Fund: 2018 School-level Education and Teaching Reform and Research Project (JF2018050) of Fuzhou University of International Studies and Trade. the Ministry of Human Resources and Social Security on Amending and Distributing the 'Interim Provisions on the Professional Eligibility System for Asset Appraisers' and the Notice on the 'Implementation Measures for the Professional Eligibility Examination for Asset Appraisers' (MHRSS Regulations [2017] No. 7) were issued to carry out the reform of asset appraisers' examination system, of which Article 10 states that "citizens with college degree or above can participate in the professional qualification examination for asset appraisers"; the National Unified Examination Registration Guide for Professional Eligibility of Asset Appraisers in 2017 is issued by China Asset Appraisal Association to point out "a college student who meets the above registration conditions and currently has not obtained a degree (degree) may apply for the examination for professional eligibility of asset appraisers". This is a major reform, which is not only conducive to the development of the asset assessment industry, but also conducive to the cultivation of asset assessment students in higher education institutions. The reform of the exam for asset appraisers is an opportunity and a challenge for the training of students in asset assessment.

Asset appraisal is an emerging profession, and just in 2006 the Ministry of Education approved the undergraduate education of the major in a few universities. Due to the short enrollment history, the "teaching" and "learning" evaluation forms of asset assessment are relatively single, and the teaching methods are mostly teacher-centered traditional teaching forms, lack of innovation, teachers have insufficient practical experience, the classroom interaction is developed hardly; students have short interest in learning asset assessment, sometimes study only for exams and make a sudden and violent learning before examination [1]. These problems have largely restricted the development of the vocation, but the reform of the exam for asset appraisers has brought a new opportunity to change the existing teaching mode. Therefore, the study on the teaching mode of Integration of Curriculum and Profession in asset appraisal under the background of exam reform for asset appraisers, has important functions and practical application significance for improving teachers' practical teaching ability, improving students' interest in learning, making students better master professional skills, enhancing employment advantages, and improving the talent training mode of asset assessment. 
II. ANALYSIS OF THE CONNOTATION AND CHARACTERISTICS OF THE TALENTS TRAINING MODE OF "INTEGRATION OF CURRICULUM AND PROFESSION" IN ASSET ASSESSMENT

"Integration of Curriculum and Profession" is a talent training mode that combines the professional certificate examination necessary for market with the professional talents training, and integrates the curriculum setting with the content of vocational qualification examination and the needs of professional positions [2, 3]. Under this mode, professional curriculum teaching should be guided by the professional qualification certificates necessary for market, purposed for full and effective employment after graduation, and combined with professional certificate examination and professional job requirements so that students can obtain "double certificates" or even "multi-certificates" after graduation, and further improve their vocational skills and comprehensive post ability and achieve high-quality employment after graduation[4]. The talent training mode of "Integration of Curriculum and Profession" in asset assessment is also mainly reflected in the two aspects, i.e. the "class", that is, the curriculum system, and the "certificate", that is, the requirements for asset assessment.

The talent training mode of "Integration of Curriculum and Profession" in asset assessment is mainly characterized by the followings: (1) In the formulation of professional talent training program of asset assessment, it is necessary to go deep into the asset assessment industry and fully understand the development trend of the entire industry and the demand for talents, to set the professional curriculum corresponding to the content of professional certificate examination, and decided reasonable talent training standard based on the actual school operation to satisfy the professional knowledge, skills and quality required for the development of the industry. (2) The talent training mode of "Integration of Curriculum and Profession" in asset assessment is a entire system, that is mainly "asset evaluation industry market demand and talent training positioning - professional job requirements and personnel training program - professional qualification certificate examination content and course syllabus -teaching of curriculum and certificate integration - vocational qualification certificate and academic degree certificate [5], covering the aspects of talent training objectives, training program preparation, curriculum setting, student guidance and motivation, internship training base construction and teacher training and etc.

\section{The CuRRENT CONSTRUCTION AND PROBLEMS OF THE}

TALENT TRAINING MODE OF "INTEGRATION OF CURRICULUM AND PROFESSION" IN ASSET ASSESSMENT IN FUZHOU
UNIVERSITY OF INTERNATIONAL STUDIES AND TRADE

Fuzhou University of International Studies and Trade is a full-time undergraduate university approved by the Ministry of Education, and it is the institution sponsored by non-profit private higher education institutions union, and the vicechairman unit and the executive vice-president unit of the Higher Education Professional Committee of the Chinese Association for Non-government Education. The school actively makes contribution to local economic and social development and actively transforms to applied universities.
After approved, it began its undergraduate enrollment for the major of asset appraisal program in 2015 to start. Due to the late start-up, the major of asset appraisal has its talent training aimed at the training of applied and complex talent of asset appraisal. The current talent training mode of Fuzhou University of International Studies and Trade in asset appraisal is mainly reflected as: (1) training standard. Students mainly study the basic knowledge and theory of asset assessment, accounting, financial management and economic law, receive basic training of the methods and skills in asset assessment, further train their basic ability in applying the asset assessment theory and methods to analyze economic issues and solve basic problems of asset assessment; (2) Course system. It includes seven modules, i.e. general education courses, professional group platform courses, professional basic courses, professional core courses, professional orientation courses, practical teaching links and quality development, of which the courses related to the professional qualification examination for asset appraisers are shown in Table 1. The current subjects of professional qualification examination for asset appraisers include "Basic Knowledge of Asset Assessment" and "Asset Assessment Practice I" (mainly including current assets assessment, long-term investment asset assessment, machinery and equipment assessment, building and construction-inprogress assessment, and resource assets assessment, other long-term asset and liability assessments, financial reporting purposed assessment and other asset assessment business presentations), Asset Valuation Practice II (mainly including corporate valuation and intangible assets assessment) as well as "Knowledge of Asset Assessment" ( mainly including accounting knowledge, financial management knowledge and economic law knowledge), but as seen from Table 1, the curriculum setting and the professional qualification examination for asset appraiser are not integrated although Fuzhou University of International Studies and Trade set the professional course in accordance with the market demand; (3) the guidance and motivation for students. The school has a mechanism for academic clubs, which provides a platform for students to further study their professional knowledge. At the same time, the school has also introduced corresponding incentive policies to encourage students to actively apply for the professional qualification examination of asset appraisers. Despite this, there are still many problems in the construction of academic clubs, such as insufficient enthusiasm for student participation, insufficient academic hours in academic clubs, etc.; (4) Internship training base. The school has signed a school-enterprise cooperation agreement with four asset appraisal companies. However, the cooperation between schools and enterprises is not enough so far. The lack of quantity and the shortcomings in cooperation have made it impossible for enterprises to provide enough internship for teachers and students, so that teachers have few opportunities to make practice in enterprises; (5) teacher training. The existing full-time teachers of asset assessment major in Fuzhou University of International Studies and Trade all are engaged in a single teaching directly after graduation, with lack of experience in asset assessment. On the other hand, the business scope of asset assessment is getting wider, but teachers have no corresponding continuing education training, leading to the disconnection of theory with practice, and the lag of their 
comprehensive practical ability behind the development of the industry. At the same time, the existing teachers of business are insufficient, which makes it impossible for students to timely understand the development of the entire asset assessment industry, and is not conducive to curriculum teaching.

TABLE I. CURRICULUM SETTING FOR PROFESSIONAL QUALIFICATION CERTIFICATE OF ASSET APPRAISER

\begin{tabular}{|c|c|c|}
\hline \multicolumn{2}{|c|}{ Course Category } & Course Title \\
\hline \multicolumn{2}{|c|}{ Professional basic course } & Basic accounting \\
\hline \multicolumn{2}{|c|}{ Professional core courses } & $\begin{array}{l}\text { Intermediate Financial Accounting I, } \\
\text { Financial Management, Economic Law, } \\
\text { Tax Law, Asset Valuation Principles, } \\
\text { Intangible Assets Assessment, Real Estate } \\
\text { Assessment, Corporater Value } \\
\text { Assessment, International Assessment } \\
\text { Criteria }\end{array}$ \\
\hline \multirow[b]{2}{*}{$\begin{array}{l}\text { Professional } \\
\text { orientated } \\
\text { course }\end{array}$} & $\begin{array}{l}\text { Limited } \\
\text { optional } \\
\text { courses }\end{array}$ & $\begin{array}{l}\text { Cost Management Accounting, Intangible } \\
\text { Assets Evaluation Case, Enterprise Value } \\
\text { Evaluation Case, Cost Management } \\
\text { Accounting, Real Estate Valuation Case } \\
\text { and Analysis, Basic System and Policy of } \\
\text { Real Estate }\end{array}$ \\
\hline & $\begin{array}{l}\text { Optional } \\
\text { Courses }\end{array}$ & $\begin{array}{l}\text { Intermediate Financial Accounting II, } \\
\text { Forest Resource Asset Valuation, } \\
\text { Mechanical and Electrical Equipment } \\
\text { Assessment, Construction Engineering } \\
\text { Assessment, Advanced Financial } \\
\text { Accounting, Asset Valuation Theory and } \\
\text { Preface, Land Valuation Cases and } \\
\text { Reports, Corporate M\&A, Land } \\
\text { Valuation Theory and Methods, Second- } \\
\text { hand Vehicle Assessment and } \\
\text { Transaction, Financial Statement } \\
\text { Preparation and Analysis }\end{array}$ \\
\hline $\begin{array}{l}\text { Concentrated } \\
\text { teaching links }\end{array}$ & practice & $\begin{array}{l}\text { Professional Cognitive Internship, Basic } \\
\text { Accounting Simulation Experiment, } \\
\text { Comprehensive Experiment of Financial } \\
\text { Accounting, Asset Evaluation Simulation } \\
\text { Experiment, Comprehensive Experiment } \\
\text { of Asset Evaluation }\end{array}$ \\
\hline Quality Develc & ment Course & Academic Club of Asset Evaluation \\
\hline
\end{tabular}

\section{PROPOSALS ON THE TEACHING REFORM OF ASSET}

EVALUATION BASED ON "INTEGRATION OF CURRICULUM AND PROFESSION"

\section{A. Focusing on Guidance - Building an Academic Club of Asset Assessment to Enhance Students' Interest in \\ Learning}

Teacher's guidance is the key to achieve the "Integration of Curriculum and Profession". According to the regulations issued by the Ministry of Human Resources and Social Security, the subjects of the exam for asset appraisers include such four courses as "Basic Knowledge of Asset Assessment", "Involved Knowledge of Asset Assessment", "Asset Assessment Practice (I)" and "Asset Assessment Practice (II)". However, the content and knowledge points covered by these four courses are numerous and complicated, and without the guidance of teachers, students will be often confused in their learning and examination preparation, so that no systematic knowledge system is formed, leading to lack of interest and impetus of learning. Therefore, addition to the class, an academic club of asset assessment should be built, which will provide a platform for students to participate in the discipline competition and examination exchange and will also help the direct interaction between teachers and students, so that we truly realize the integration of "classes, certificates, competitions" and improve students' interest in learning.

\section{B. Promoting the Integration - Integrating the Examination Syllabus of Asset Assessment into the Professional Curriculum System, and Adjusting the Professional Training Program}

Teaching should be made according to the requirements of examination syllabus for asset appraisers and in combination with the basic knowledge of the core curriculum theory of the major with the professional certificate examination syllabus, to achieve the docking of curriculum and professional certificate examination. Through collective discussion, analyze professional qualification standards, introduce them into professional training programs, and adjust professional training programs to make it include both professional standards and major setting rules of asset assessment. While achieving the academic education of asset assessment, students can also participate in the vocational qualification examination to obtain the professional qualification certificate of asset appraiser, so that they meet the requirements of professional standards and achieve double-certificate graduation, and further increase the employment advantages.

\section{Strong Practice - Strengthening the Cooperation Between Schools and Enterprises and the Construction of Practice Base Outside the School, and Introducing the Industry Lecturers for Instruction}

Internship and practice are an important part of the "Integration of Curriculum and Profession" mode, and the cultivation of students' practical ability is an important element of the asset evaluation personnel training plan. Adopt the teaching method of theoretical and practical combination, and try to connect the course learning with professional positions and work circumstance as much as possible, and to enhance students' professional skills. To strengthen professional skills training, we must enhance the cooperation between schools and enterprises and the construction of off-campus practice bases, organize students to do probation and post internships in enterprises after the completion of basic theory courses, for learning relevant job skills and understanding the relevant job requirements. At the same time, we should actively introduce the industry lectures for instruction, especially the courses with strong profession such as "Mechatronics Equipment Evaluation", "Enterprise Value Assessment", "Real Estate Evaluation", "Intangible Assets Evaluation", etc., with their rich practical experience, to guide students in skills training and professional qualification certification.

\section{Enhancing the Force of Teachers - Improving the \\ Quality of Professional Teachers in Asset Assessment and Optimizing the Structure of Teachers}

The instructors of asset assessment are the key condition for implementation of "Integration of Curriculum and Profession", and from the mode of "Integration of Curriculum and Profession", professional teachers must have solid and 
complete professional theoretical foundations, and must have excellent teaching practice knowledge and experience. Most of the existing teachers have not really engaged in business of asset assessment, and teachers' knowledge structure and teaching ability hardly meet the professional development of asset assessment, and hardly meet the needs of students for learning. Therefore, we must establish a high-quality teaching team with the professional characteristics of asset assessment, encourage teachers to obtain the professional qualification certificate of asset appraiser, and meanwhile actively encourage the teachers to make a post practice in the enterprises of asset assessment, so as to build a "doublemastered and double-skilled" teacher team. On the other hand, we should actively establish cooperative relations with the provincial asset appraisal association and participate in the training of follow-up education of asset appraisers developed by the appraisal association, and continuously update and expand the business of asset appraisal and related theoretical knowledge so as to make the teaching more targeted.

\section{CONCLUSION}

The training of applied talents in asset assessment must meet the needs of the asset assessment industry and socio and economic development. The "Integration of Curriculum and Profession"-oriented talent training mode of asset evaluation is the main theme of application-oriented undergraduate colleges for current development of vocational education, and it is substantially to make the professional teaching in schools closely connected with the demands of asset assessment industry and further change the problems such as slow construction of the "double-mastered and double-skilled" teaching team, superficial integration of production and education, and unstable internship and training base platform for students, so that students can obtain both academic certificates and professional qualification certificates after graduation, and improve their professional skills. The "Integration of Curriculum and Profession" talent training mode is an effective way to improve the teaching reform of asset assessment in applied universities, which can truly adapt the talent training of asset assessment to the needs of the industry, and it is the key to improving students' employment advantages and achieving employment orientation.

\section{REFERENCES}

[1] Zheng Huijuan, Li Fuquan. Thoughts on the Construction of Undergraduate Courses of Asset Evaluation under the New Situation[J]. China Assets Appraisal, 2017, (9): 39-42.

[2] Wang Hongman. Exploration and Research on the " Integration of Curriculum and Profession" in the Cultivation of Financial Talents in Independent Colleges - Taking the School of Law and Business of Hubei University of Economics as an Example[J]. Journal of Hubei University of Economics (Humanities and Social Sciences), 2016, 13(11): 209-210.

[3] Chen Shuwu. Exploration and Practice on the Talent Cultivation Mode of "Integration of Curriculum and Profession" in Vocational and Technical Colleges of Finance and Economics[J]. Vocational and Technical Education, 2017, (35): 30-33.

[4] Li Haiyan. Research on the Training Mode of Financial Management in Private Applied Colleges and Universities Based on the Guidance of "Curriculum and Profession Integrated, Competition Leading" Action[J].
Journal of Shandong Agricultural Engineering University, 2016, 33(10): 27-28.

[5] Ding Rong, Long Wenbin. Integration of Curriculum and Profession Exploration on Career-oriented Talents Training Mode of Financial Management [J]. Journal of Guangdong Polytechnic Normal University, 2017, 38(3): 27-33. 